\title{
Spontaneous late in-the-bag intraocular lens dislocation after can-opener capsulotomy: case report
}

\author{
Deslocamento espon tâneo e tardio de lente intra-ocular "in-the-bag" após capsulotomia \\ tipo abridor de latas: relato decaso
}

\author{
Roberto Pinto Coelho ${ }^{1}$ \\ Maria Cristina Zanatto ${ }^{2}$ \\ Jayter Silva de Paula ${ }^{3}$ \\ Erasmo Romão ${ }^{4}$
}

\begin{tabular}{|l|}
\hline ABSTRACT \\
\hline We report a case of a 58-year-old man presenting with a spontaneous and \\
late in-the-bag intraocular lens dislocation to the vitreous. A previous \\
uneventful extracapsular cataract extraction with can-opener style capsu- \\
lotomy and implantation of a polymethylmethacrylate three-piece lens was \\
performed and, two years after the surgery, the patient developed capsule \\
contraction syndrome with a fibrotic ring formation and dislocation of the \\
intraocular lens. Although uncommon and related mainly to continuous \\
curvilinear capsulorhexis, capsule contraction syndrome occurs in patients \\
undergoing extracapsular cataract surgery with can-opener style and \\
polymethylmethacrylate lens implantation, and can be the causative factor \\
of intraocular lens dislocation.
\end{tabular}

Keywords: Cataract; Cataract extraction; Lens implantation, intraocular/adverse effects; Postoperative complications; Case reports [Publication Type]

\section{INTRODUCTION}

Dislocation of a posterior chamber intraocular lens (IOL) typically occurs after decentralization, followed by migration to the vitreous cavity through a rupture area of the equatorial portion of the posterior capsule ${ }^{(1-2)}$ or through posterior capsulotomy with neodymium: YAG laser ${ }^{(3-4)}$.

A new type of IOL dislocation has been recently described, involving total IOL luxation within an intact capsular bag. Various reports have correlated this complication with countless predisposing factors, although IOL dislocation can occasionally occur in a spontaneous manner ${ }^{(5-9)}$.

We report here a rare case of late and spontaneous IOL dislocation with contraction of the capsular bag towards the vitreous cavity. The patient was successfully treated with removal of the dislocation IOL with the capsular bag, and scleral fixation of another IOL in the ciliary sulcus.

\section{CASE REPORT}

A 58-year-old white male reported progressive visual clouding in the right eye of approximately three-year duration. The visual acuity of this eye was hand motions and biomicroscopy revealed a total cataract with no other signs of ocular involvement. Mode A and B ultrasonography revealed an eye of normal aspect and axial diameter of $22.0 \mathrm{~mm}$.

Extracapsular cataract extraction with can-opener capsulotomy was performed, followed by implant of a three-piece intraocular lens of polymethylmethacrylate (PMMA) with prolene (polyvinylidene fluoride) haptics 
measuring $7 \mathrm{~mm}$ in diameter ( +24.00 dioptries) in the capsular bag, with no untoward events. After three months, the patient had good visual acuity (20/25 with plane $-0.50 \times 175)$ and no complications.

Two years after surgery, the patient returned complaining of severe low visual acuity (hand motions) in the operated eye, which was worse in the morning. He denied trauma or other ocular changes. Slit-lamp examination revealed inferior and nasal subluxation of the IOL inside a thickened and contracted capsular bag, with dislocation toward the posterior pole in dorsal decubitus. No flare or cells were detected in the anterior chamber, nor was conjunctival hyperemia observed. Intraocular pressure was $14 \mathrm{mmHg}$ and no other changes were detected by fundoscopy (Figure 1).

Because of his complaint of low vision, the patient was submitted to vitrectomy via the "pars plana", with IOL removal through an $8 \mathrm{~mm}$ limbar incision and implant of a new IOL with the same characteristics as the previous one in the ciliary sulcus by scleral fixation.

Macroscopic examination of the material removed by surgery revealed retraction and thickening of the entire capsular bag, as well as the formation of a fibrotic ring in the area of the anterior capsulotomy causing concentric contraction and total curving of the IOL haptics (Figure 2).

On occasion of the latest ophthalmologic evaluation six months after surgery, the patient had no complaints or ocular complication and his visual acuity was 20/30 with plane $-2.00 \times 175$.

\section{DISCUSION}

The capsular contraction syndrome manifests as an exaggerated reduction of the opening of a previous anterior capsulotomy and of the diameter of the equatorial portion of the capsular bag after cataract surgery. It may be due to a contraction caused by fibrous metaplasia of residual epithelial cells of the lens

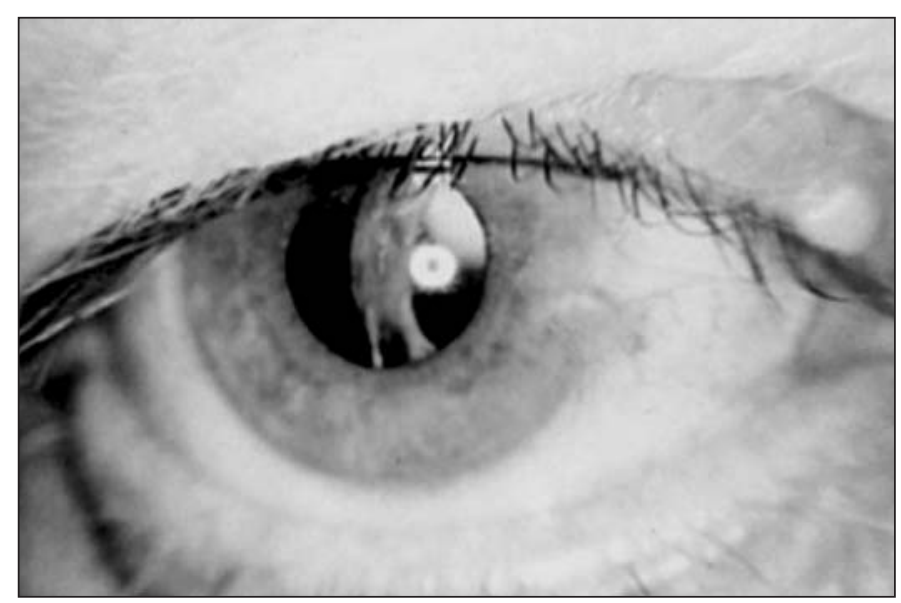

Figure 1 - Slit-lamp photograph of nasal and inferior subluxation of a right eye IOL two years after extracapsular cataract extraction. Note IOL dislocation within the thickened and contracted capsular bag associated with changes in zonular support ${ }^{(10)}$. These two factors, individually or as a whole, may cause IOL dislocation with an intact capsular bag, with numerous associated causes ${ }^{(11)}$.

When recent ocular trauma is ruled out as the cause of inthe-bag IOL dislocation, other predisposing factors may lead to zonular fragility, such as advanced age, diabetes mellitus, pseudoexfoliation, retinitis pigmentosa, and uveitis ${ }^{(12)}$.

In the pseudoexfoliation syndrome, which is a predisposing factor commonly related to delayed IOL dislocation, there is accumulation of acellular fibrillar material in the zonular fibers, which become friable, with a reduction in their tension strength followed by rupture ${ }^{(9,13)}$. Pseudoexfoliation syndrome is a relatively common disorder among elderly patients, affecting $8 \%$ to $35 \%$ of them after 70 years of age, but the patient in question was relatively young and did not present any sign of the disease ${ }^{(13)}$.

Spontaneous in-the-bag IOL dislocation to the vitreous is a rare condition, mainly reported after the advent of phacoemulsification with continuous curvilinear capsulorhexis, and is also related to capsular contraction syndrome ${ }^{(5-9)}$. During phacoemulsification, the use of high vacuum, high aspiration and high irrigation pressure may provoke zonular injury ${ }^{(12)}$.

In addition, a higher frequency of capsular contraction is observed in cases of smaller capsulorhexis, probably owing to the permanence of a larger number of residual epithelial cells of the crystalline lens below the anterior capsule, with an increased chance of metaplasia ${ }^{(10)}$. The metaplasia of these epithelial cells in myofibroblasts may progress with induction of fibrosis and later contraction ${ }^{(14)}$. Thus, an unbalance between the centrifugal and centripetal forces of the capsular bag may cause rupture of the zonule ${ }^{(10,14)}$.

Other factors that influence fibrosis and capsular contraction are the type and size of the previous capsulotomy, the material and design of the intraocular lens and the type of fixation ${ }^{(11)}$.

Intraocular one-piece PMMA lenses with rigid haptics are more resistant to capsular contraction than lenses with flexible haptics ${ }^{(15)}$. However, there is only one report of an implant

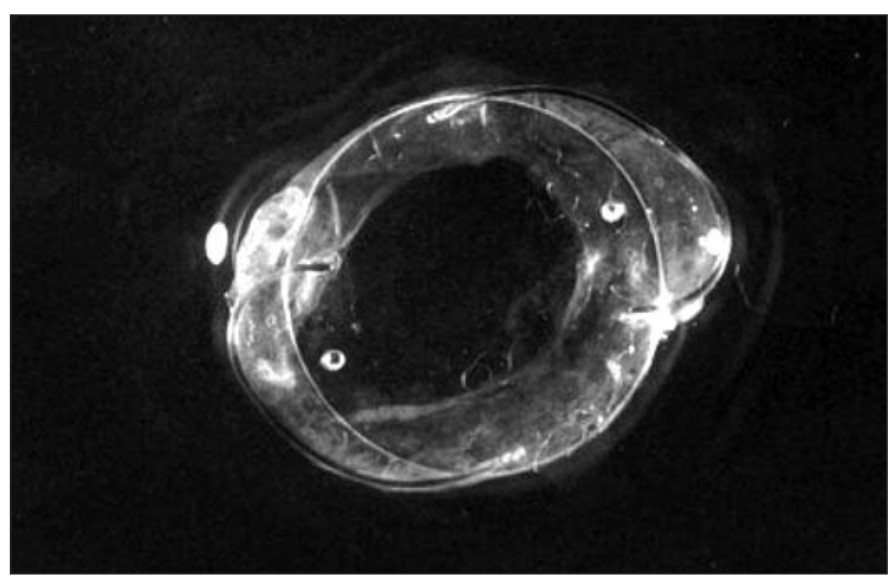

Figure 2 - IOL photograph inside the capsular bag after surgical removal. Note capsular contraction with a curved prolene haptic lens 
of a PMMA IOL after envelope-type capsulotomy and spontaneous total IOL in-the-bag dislocation to the vitreous ${ }^{(16)}$.

In the present case, no signs of diseases related to zonular fragility were observed during patient follow-up. Macroscopic examination revealed that the prolene haptics, which are more flexible, were greatly curved, demonstrating the occurrence of capsular contraction and consequent spontaneous zonular rupture, despite the previous can-opener capsulotomy.

Previous reports, taken together with the present one, demonstrate that, even though spontaneous in-the-bag IOL dislocation is rarely observed in can-opener capsulotomies $^{(10)}$, the type of IOL used, of PMMA with flexible haptics, may be one of the main related factors, with careful late postoperative observation being recommended in such cases.

\section{RESUMO}

Os autores relatam o caso de homem de 58 anos de idade que apresentou deslocamento espontâneo e tardio de lente intraocular dentro do saco capsular para o vítreo. O paciente havia sido submetido a facectomia extracapsular com capsulotomia do tipo abridor de latas e implante de lente de polimetilmetacrilato de três peças sem intercorrências e, dois anos após a cirurgia, desenvolveu síndrome de contração capsular com formação de um anel fibrótico na cápsula e subluxação da lente intra-ocular. Embora incomum e relacionada principalmente com capsulorexe curvilínea contínua, a síndrome de contração capsular pode ocorrer em pacientes submetidos a facectomia extracapsular com capsulotomia do tipo abridor de latas e implante de lente de polimetilmetacrilato e pode ser o fator causador do deslocamento da lente intra-ocular.

Descritores: Catarata; Extração de catarata; Implante de lente intra-ocular/efeitos adversos; Complicações pós-operatórias; Relato de caso [Tipo de publicação]

\section{REFERENCES}

1. Smiddy WE, Ibanez GV, Alfonso E, Flynn HW Jr. Surgical management of dislocated lenses. J Cataract Refract Surg. 1995;21(1):64-9.

2. Carlson AN, Stewart WC, Tso PC. Intraocular lens complications requiring removal or exchange. Surv Opthalmol. 1998;42(5):417-40.

3. Tuft SJ, Talks SJ. Delayed dislocation of foldable plate-haptic silicone lenses after Nd: YAG laser anterior capsulotomy. Am J Ophthalmol. 1998;126(4):586-8.

4. Petersen AM, Bluth LL, Campion M. Delayed posterior dislocation of silicone plate-haptic lenses after neodymium: yag capsulotomy. J Cataract Refract Surg. 2000;26(12):1827-9.

5. Nishi O, Nishi K, Sakanishi K, Yamada Y. Explantation of endocapsular posterior chamber lens after spontaneous posterior dislocation. J Cataract Refract Surg. 1996;22(2):272-5.

6. Zech JC, Tanniére P, Denis P, Trepsat C. Posterior chamber intraocular lens dislocation with the bag. J Cataract Refract Surg. 1999;25(8):1168-9.

7. Shigeeda T, Nagahara M, Kato S, Kunimatsu S, Kaji Y, Tanaka S, et al. Spontaneous posterior dislocation of intraocular lenses fixated in the capsular bag. J Cataract Refract Surg. 2002;28(9):1689-93.

8. Tsilou E, Rubin BI, Abraham FA, Kaiser-Kupfer M. Bilateral late posterior chamber intraocular dislocation with the capsular bag in a patient with gyrate atrophy. J Cataract Refract Surg. 2004;30(7):1593-4.

9. Jehan FS, Mamalis N, Crandall AS. Spontaneous late dislocation of intraocular lens within the capsular bag in pseudoexfoliation patients. Ophthalmology. 2001;108(10):1727-31.

10. Davison JA. Capsule contraction syndrome. J Cataract Refract Surg. 1993; 19(5):582-9.

11. Gross JG, Kokame GT, Weinberg DV. Dislocated in-the-bag intraocular lens study group. In-the-bag intraocular lens dislocation. Am J Ophthalmol. 2004; 137(4):630-5.

12. Assia EI, Apple DJ, Morgan RC, Legler UF, Brown SJ. The relationship between the stretching capability of the anterior capsule and zonules. Invest Ophthalmol Vis Sci. 1991;32(10):2835-9.

13. Eagle RCJ Jr, Spencer WT. Lens. In: Spencer WH, editor. Ophthalmic pathology: an atlas and textbook. 4th ed. Philadelphia: WB Saunders; 1996. p.394.

14. Joo CK, Shin JA, Kim JH. Capsular opening contraction after continuous curvilinear capsulorhexis and intraocular lens implantation. J Cataract Refract Surg. 1996;22(5):585-90.

15. Hayashi K, Hayashi H, Nakao F, Hayashi F. Comparison of decentration and tilt between one piece and three piece polymethylmethacrylate intraocular lenses. Br J Ophthalmol. 1998;82(4):419-22.

16. Tognetto D, Agolini G, Ravalico G. Spontaneous dislocation into the vitreous of a poly(methylmethacrylate) disc lens 9 years after surgery. J Cataract Refract Surg. 1999;25(2):289-92. 